Physiol Behav. 2011 July 25; 104(1): 69-75. doi:10.1016/j.physbeh.2011.04.045.

\title{
Neurobiology of Aversive States
}

\author{
Erin N. Umberg ${ }^{1}$ and Emmanuel N. Pothos ${ }^{1,2}$ \\ 1 Department of Molecular Physiology and Pharmacology, Program in Pharmacology \& \\ Experimental Therapeutics, Tufts University School of Medicine, Boston, MA \\ 2 Department of Molecular Physiology and Pharmacology, Program in Neuroscience, Tufts \\ University School of Medicine, Boston, MA
}

\begin{abstract}
Hoebel and colleagues are often known as students of reward and how it is coded in the CNS. This article, however, attempts to focus on the significant advances by Hoebel and others in dissecting out behavioral components of distinct aversive states and in understanding the neurobiology of aversion and the link between aversive states and addictive behaviors. Reward and aversion are not necessarily dichotomous and may reflect an affective continuum contingent upon environmental conditions. Descriptive and mechanistic studies pioneered by Bart Hoebel have demonstrated that the shift in the reward-aversion spectrum may be, in part, a result of changes in central dopamine/ACh ratio, particularly in the NAc. The path to aversion appears to include a specific neurochemical signature: reduced dopamine activity and increased ACh activity in "reward centers" of the brain. Opioid receptors may have a neuromodulatory role on both of these neurotransmitters.
\end{abstract}

\section{Keywords}

Behavior; Reward; Aversion; Stress; Drug Withdrawal; Opiate; Food Deprivation; Conditioned Taste Aversion; Conditioned Place Preference; Pain; Dopamine; Acetylcholine; Nucleus Accumbens; Striatum; Obesity; Eating Disorders; Alcohol

\section{Introduction}

Reward paradigms have been studied for decades using approach and self-stimulation measures. The state opposite of reward may be considered "aversion", which is reflected in avoidance and stimulation escape measures [1]. The Mirriam-Webster Dictionary defines aversion as: a) a feeling of repugnance toward something with a desire to avoid or turn from it; b) a settled dislike: antipathy; c) a tendency to extinguish a behavior or to avoid a thing or situation and especially a usually pleasurable one because it is or has been associated with a noxious stimulus. Although aversive states have been studied extensively in the psychological context [2-8], the neurobiology behind aversion has received far less attention. In part, this may be because the definition of aversion is seemingly ambiguous

() 2011 Elsevier Inc. All rights reserved.

For correspondence: Emmanuel N. Pothos, Ph.D., Department of Molecular Physiology and Pharmacology, Tufts University School of Medicine, Medical and Veterinary Building, Suite 201, 136 Harrison Avenue, Boston, MA 02111, tel: 617-636-6778, fax: 617-636-6738, Emmanuel.Pothos@tufts.edu.

Publisher's Disclaimer: This is a PDF file of an unedited manuscript that has been accepted for publication. As a service to our customers we are providing this early version of the manuscript. The manuscript will undergo copyediting, typesetting, and review of the resulting proof before it is published in its final citable form. Please note that during the production process errors may be discovered which could affect the content, and all legal disclaimers that apply to the journal pertain. 
when applied to neurobiological pathways. Different criteria may apply to acute versus chronic aversion, perhaps reflecting neuro-mechanistic differences. This review will explore these differences with an emphasis on the work by Bartley G. Hoebel and others on implicated neurotransmitters.

\section{Behavioral Measures}

A number of protocols have been constructed to induce aversive states acutely in rodents, such as restraint stress, trauma to an extremity (tail or foot shock), administration of nauseainducing agents (i.e. lithium chloride), intracranial electrode stimulation, or intraperitoneal acetic acid administration [9-12]. Behavioral measures (i.e., ultrasonic vocalizations and behavioral reactivity) can then be used to interpret the degree to whether the aforementioned stimuli are indeed aversive $[9,13]$. Ultrasound vocalizations at $22 \mathrm{kHz}$ are important components of the unconditioned defensive behavior repertoire in rats and a reliable measure of fear and aversion in laboratory animals [194]. Therefore, the frequency of the vocalization response is the important parameter that separates a reflex from a response indicative of an aversive state. Other researchers measure avoidance motivation in an aversive state [14], or use classic fear conditioning to determine how quickly an animal learns to respond with fear to a neutral stimulus which has been contingently paired with an aversive stimulus [15-17].

Conditioned place aversion (CPA) is also used to evaluate preferences for environmental stimuli that have been associated with aversive states. This procedure involves several trials where the animal is presented with a negative stimulus paired with placement into a distinct environment containing various cues (i.e. tactile, visual, and/or olfactory). When later tested in the normal state, withdrawals and the amount of time spent in compartments previously associated with negative stimuli serve as an indicator of preference and a measure of reward learning versus aversion [14].

Hoebel and colleagues have used electrical stimulation studies to explore reward and aversion [12, 18-26]. Electrical stimulation of the hypothalamus is known to be either rewarding or aversive depending on the location of the stimulation electrode [1, 25]. While electrode placement in the lateral hypothalamus (LH) is generally considered a positive reinforcer (promotes self-stimulation), more medial electrode placement causes signs of aversion and elicits stimulation-escape responses where an animal lever presses to stop stimulation $[1,12]$. Therefore, self-stimulation and stimulation-escape are sometimes used to measure positive and negative reinforcers associated with appetitive and aversive states, respectfully.

Precipitation of drug withdrawal, particularly opiate withdrawal, is another frequently used approach in inducing an aversive state that can be easily demonstrated through behavioral criteria and a well-defined physiological response [134]; and protocols of chronic food deprivation that induce significant weight loss can be quite useful in studying not only a prolonged aversive state but also the motivation to obtain a powerful reinforcer like food to reverse it [135].

\section{Acute versus chronic aversion}

A distinct incident of mild pain or stress can cause an acutely aversive state, which an animal will try to escape. Upon cessation of the aversive stimuli, the animal tends to recover from the aversive state, psychologically and neurochemically. However, repeated stressors can cause a chronic state of aversion, which has long-lasting ramifications, even after the stimulus has been removed. Examples of chronic aversion may include chronic food deprivation, obesity, bulimia nervosa, drug withdrawal, learned negative associations, 
depression, and chronic pain. Clinical studies have shown that chronic pain patients present several psychological disturbances such as high levels of anxiety and depression [27, 28], stress $[29,30]$, or reduced sleep quality [31]. These disturbances are likely reflective of central monoamine aberrations. Moreover, chronically aversive states result in neuroanatomical alterations such as a decrease in grey matter density [32]. Acute versus chronic states of aversion may reflect distinct neurochemical phenomena, as discussed below.

\section{Neurobiology}

\subsection{Dopamine}

The majority of research on mesoaccumbens dopamine focuses on appetitively-motivated behaviors. Dopamine release in the nucleus accumbens (NAc), striatum, and medial prefrontal cortex is potentiated by rewarding stimuli, such as food intake [33-35], drugs of abuse [33, 36-38], and sexual behavior [39, 40]. However, mesolimbic dopamine is also involved in aversively motivated (i.e. "avoidance") behaviors [41-44]

Acute states of aversion (i.e. immediate pain) have been shown to increase dopamine activity in mesolimbic areas traditionally associated with reward, although regional variations exist in degree and time course [45-53]. This increase in striatal dopamine release is supportive of other lines of investigation suggesting a role for striatal dopamine in the response to acute stress; for example, destruction of the dopaminergic neurons of the nigrostriatal bundle reduces the capacity of rats to respond appropriately to stress [54].

However, not all aversive states reflect an increase in dopamine activity. When intraoral saccharine infusions are repeatedly paired with lithium chloride (nausea-evoking agent), animals in the conditioned taste aversion group experience significant decreases in NAc dopamine when given the saccharine conditioned stimulus alone [55]. Because sweet taste (saccharine) is usually associated with reward (and enhanced dopamine), this demonstrates the ability of learned aversions to alter neurochemical responses.

Medial hypothalamic (MH) stimulation, which has been considered to cause a primarily aversive state [1, 12], causes a significant decrease in extracellular dopamine [25]. However, when rats can lever-press to escape $\mathrm{MH}$ stimulation, NAc dopamine increases instead. This is similar to findings from Cabib and colleagues that show that the NAc dopamine metabolite, 3-methoxytyramine, decreases when foot shock is inescapable and increases when animals are allowed to control the painful shock experience [56]. Inescapable foot shock may be analogous to learned helplessness or depression, which are more chronic conditions.

The seemingly dichotomous nature of dopamine responses to stressful stimuli may reflect different neurobiological factors contributing to acute versus chronic states of aversion. Although an acutely painful stimulus enhances dopamine activity globally in the brain, chronic pain stimuli seem to downregulate dopaminergic transmission [28, 53, 57-60]. Interestingly, fibromyalgia patients, who are arguably in a chronic state of aversion, do not experience the same increases in dopamine in response to acute pain stimuli as healthy controls [28]. However, the perceived rating of the pain is greater for these patients. Thus, it is possible that the enhanced dopamine response to acute stress discussed above may be a compensatory action in healthy individuals to dampen perception of the stressful stimulus. In chronic states of aversion, this adaptation is lacking.

Depression and learned helplessness are other forms of chronic aversion marked by decreased dopamine activity. Clinical studies have demonstrated increased levels of 
dopamine transporter (DAT) in depressed patients [61], which results in greater reuptake and shortened dopamine signaling, and medications which raise dopamine levels have antidepressant effects [62-64]. In animals, behavioral depression can be inferred using the forced-swim test, which measures swimming escape efforts vs. passive floating [65]. In the forced-swim test, a rat gives up trying to escape on the second day, demonstrating learned helplessness, and extracellular dopamine in the NAc subsequently decreases [21, 66]. Park and colleagues found that they could induce learned helplessness in mice by prolonged exposure to dopamine [67], suggesting that repeated stressors (which acutely release dopamine) may cause neuroadaptations that result in a downregulated dopamine system.

Similarly, drugs of abuse, which repeatedly release excess dopamine in central reward regions, may trigger a chronic aversive state as the brain compensates by decreasing basal dopaminergic activity. Numerous studies have demonstrated diminished dopamine neurotransmission during withdrawal from addictive substances [68-74]. In cases of pharmacologically induced withdrawal, dopamine also decreases $[71,75]$ and the threshold for brain-stimulation reward rises [76].

In the past decade, Bartley Hoebel's work has demonstrated that certain patterns of binge eating on sugar can cause an aversive state with dopaminergic similarities to drug addiction $[21,77-82]$. While intermittent binging on sugar repeatedly releases dopamine in the NAc [82], the resulting state of obesity is marked by decreased dopamine activity [83-85]. Other changes in the dopamine system, such as increases in D1 receptor binding, decreases in D2 receptor binding, and increases in D3 receptor mRNA, are also common to aversive states that follow sugar bingeing [79, 80, 86-88] or drug withdrawal [86, 89-91]. Furthermore, "sugar-dependent" rats experience somatic signs of withdrawal, such as teeth chattering, forepaw tremor, and head shakes when withdrawal is precipitated with an opioid antagonist (naloxone), or when sugar is removed [79]. Electrical stimulation studies have also produced evidence of an aversive state following overeating. Lateral hypothalamic electrode placement, which usually produces self-stimulation, instead results in escape responding after overeating [12].

Like overeating, undereating can also trigger an aversive state with changes in the dopamine system. Restricted eating with weight loss decreases extracellular dopamine in the NAc and significantly alters dopamine response to amphetamine, morphine, and food intake [92].

Chronic food deprivation and subsequent weight loss increases drug-seeking behavior and voluntary drug intake in animals [93-96] and individuals with Anorexia Nervosa (AN) have been found to have higher rates of substance abuse [97, 98]. Clinical studies also demonstrate decreased dopaminergic transmission in AN [99-101].

Overall, aversive stimuli seem to enhance dopamine activity in the acute sense. Over time though, the brain adapts to counteract these dopamine surges by downregulating dopaminergic transmission. The decreased dopaminergic neurotransmission secondary to its activation may be a consequence of prolonged excitatory stimulation of dopaminecontaining neurons by opioids (discussed later in this paper), which results in depletion of dopamine stores and/or depolarization blockade in excitability of dopamine cells [53]. Other events such as receptor internalization, upregulation of D2-Short autoreceptors, decreased transmitter synthesis, increased reuptake, or a combination of the above could also contribute to a compromised dopamine system.

\subsection{Acetylcholine}

Acetylcholine (ACh) may interact with dopamine to modulate approach and avoidance behaviors in the reward-aversion spectrum. Hoebel and colleagues (2007) suggest that the dopamine/ACh balance in the NAc may affect motivation (and motivational disorders) 
analogous to movement (and movement disorders) where dopamine enables a person to start moving, while ACh acts as a control to prevent over-responding and facilitate stopping [21]. Other studies support a counter-regulatory role of dopamine and ACh. In the striatum, dopamine excites while ACh inhibits GABA/dynorphin output via a predominance of D1type receptors and dopamine inhibits while ACh excites GABA/enkephalin output cells via D2-type receptors [102, 103].

Contrary to dopamine, which typically fosters approach and states of reward, ACh release in the nucleus accumbens correlates with the onset of acute and maintenance of chronic aversive states. Further studies on the effect of cholinergic receptor antagonism in the nucleus accumbens on the expression of such states would illustrate as to whether this is a causal relationship. However, regional variations may exist based on the nature of the stressor (acute versus chronic). Restraint stress or foot-shock immediately stimulates ACh release in the hippocampus, but not in the NAc [104-106]. ACh release in the NAc may be more involved in slower onset states of "aversion", reflecting changes in reward evaluation. For example, ACh in the NAc has a role in the onset of satiation, with extracellular increases in the NAc towards the end of a meal [81, 107]. While the increase in dopamine during feeding signals food "reward", the increase in NAc ACh may code for the aversive aspects of gastric distention. This increase in ACh is attenuated with sham feeding where food drains from a gastric fistula after ingestion [81]. Thus, the food-induced dopamine release goes unopposed in sham-feeding, which may be analogous to purging in Bulimia Nervosa.

Other studies also indicate that enhanced NAc ACh may reverse hedonistic eating and contribute to food aversion. Endogenous appetite suppressants, such as hypothalamic dopamine, serotonin, and CCK, act via the NAc by releasing ACh [108] and synthetic appetite-suppressant drugs also release ACh in the NAc [109]. This indicates that the rewarding aspects of food intake may become aversive as satiation is reached through mechanisms that increase ACh. Likewise, if food intake becomes aversive by pairing the food with lithium chloride-induced nausea, the taste of that food significantly increases ACh in the NAc [11]. Thus, food (in particular, sweet taste), can release dopamine or ACh depending on the learned physiological consequences. Moreover, elevated ACh is sufficient by itself to cause a taste aversion [110]. This effect may be mediated by enhanced ACh acting at M1 receptors that oppose dopamine's D2 receptor effects on the indirect GABA output pathway for behavior inhibition $[111,112]$.

Further evidence that aversive states are marked by increased ACh comes from drug-seeking and drug withdrawal studies. Drugs that increase NAc ACh inhibit cocaine selfadministration [109, 113, 114], and block cue-induced heroin seeking [115] and conditioned place preference, which is reversed by selective ablation of ACh neurons [116]. Naloxoneprecipitated drug withdrawal, a classic state of aversion, causes dopamine to decrease and ACh to be released instead $[71,75,117,118]$. Nicotine and ethanol withdrawal are also marked by a significant decrease in dopamine and increase in ACh [72, 73]. Similarly, aversive hypothalamic stimulation increases the level of extracellular ACh in the NAc. Animals increase lever pressing to escape this ACh-mediated state [24]. Acute administration of drugs that directly stimulate dopaminergic reward pathways (i.e. nicotine, amphetamine, cocaine) increases NAc ACh, but has a larger effect on dopamine than ACh, in terms of percent increase. This suggests that the dopamine/ACh ratio may be the key factor, rather than absolute levels, in creating a rewarding versus aversive state.

In states of depression, as measured by escape efforts in the forced swim test previously described, basal ACh levels remain elevated while dopamine decreases when behavior is depressed [119]. Antidepressants are known to restore escape swimming [120], and thus, Hoebel and colleagues hypothesized that an antidepressant drug (i.e. serotonin enhancer) 
should also lower ACh. They confirmed this hypothesis and found that the serotonin-1a receptor is one of the relevant receptors mediating this effect [111, 121]. Because local bilateral injection of a muscarinic agonist (arecholine) depresses swimming behavior, and the M1 antagonist, pirenzepine, increases escape efforts [112], ACh may be working through the M1-type receptor to influence depression [21]. Notably, this is not a locomotor effect because these manipulations do not cause hyperactivity in an open field test [112].

In summary, it appears that high ACh, especially when central dopamine is low, may generate an aversive state [21] and regional variations in ACh may reflect differences in chronic or slower-onset stressors versus acute stressors.

\subsection{Opioids}

As with dopaminergic transmission, mu-opioid transmission is acutely enhanced by stressful stimuli $[13,122,123]$, while chronic states of aversion result in a downregulation of muopioid activity [57, 124-126]. This is likely a result of desensitization due to repeated release of endogenous endorphins from aversive events, such as chronic pain [122, 123, 127]. Common pharmacological treatments for chronic pain result in further stimulation of the opioid system, specifically at mu-opioid receptors. An interesting phenomenon in chronic pain patients is the diminished abuse potential of common analgesics, such as morphine and other $\mu$-opioid agonists [57, 128, 129]. Some studies suggest activation of the endogenous kappa-opioid-dynorphin system by aversive stimuli may result in the suppression of the development of rewarding effects produced by morphine and drugs of abuse [57, 130-134]. Unlike activation of mu-opioid receptors that results in euphoria, activation of kappa-opioid receptors is associated with dysphoria $[135,136]$ and many of the aversive effects of stress are blocked by kappa-opioid receptor antagonists [135, 137, 138].

Dynorphin is the primary endogenous kappa opioid receptor ligand, and, as a co-transmitter in one of the GABA output pathways, can inhibit dopamine neurons [131-134, 139]. Excessive levels of dynorphin are linked to depression, possibly due to decreased dopaminergic transmission [139-141]. Aversive states associated with chronic stress [137] and learned helplessness [142] increase dynorphin expression, and thus, dynorphin may be a therapeutic target to attenuate states of aversion.

Contrary to kappa-opioid activation, sustained sadness conditions are associated with a significant deactivation in $\mu$-opioid neurotransmission, demonstrating dynamic changes in $\mu$ opioid activity in response to experimentally induced negative affective states [143-145]. Women with Major Depressive Disorder (MDD) also demonstrate a reduction in mu-opioid binding potential at baseline (in the absence of an emotional challenge) [143]. Thus, depressive states may reflect an opioid imbalance in which the kappa-opioid system is overactive while the mu-opioid system is underactive.

Other aversive states are also associated with changes in opioid neurotransmission. Although binge-eating, particularly of palatable foods, stimulates mu-opioid receptors [146149], individuals with BN have lower levels of $\beta$-endorphin [150] and decreased $\mu$-opioid receptor binding in the insular cortex [151], suggesting desensitization. Furthermore, the mu-opioid antagonist, naloxone, reduces the consumption of sweet high-fat foods in obese and lean female binge-eaters [152]. In binge eating rats, Kelley and colleagues have demonstrated a decrease in enkephalin gene expression in the NAc [153]. On the other end of the eating spectrum, Demitrack et al. (1993) found a decrease in $\beta$-endorphin levels in underweight anorexic individuals [154], reflecting that aversive states resulting from both under- and overeating may have diminished opioid functioning. 
The state of aversion that results from repeated use of drugs of abuse is also partially mediated by opioidergic alterations. Whether directly or indirectly, nearly all addictive substances are associated with the release of endogenous opioids [155-160]. In cocainedependent [161] and alcohol-dependent subjects [162], drug abstinence is associated with an upregulation of mu-opioid receptor binding that is proportional to drug craving. This may reflect a hyper-sensitization of receptors to compensate for decreased endogenous opioid transmission resulting from repeated drug assault. For example, acute alcohol intake in animals increases beta-endorphin levels [160], while habitual alcohol consumption leads to lowered beta-endorphin levels [163]. Dynorphin expression is also induced in the NAc and related striatal regions after exposure to drugs of abuse, an effect that seems to be mediated by the gene transcription factor CREB (cAMP response element binding protein) [164]. This could also contribute to the dysphoric states associated with drug addiction.

Opioid agonists and antagonists alter the dopamine/ACh balance, which may be one way they influence states of euphoria versus dysphoria. As mentioned previously, states of aversion/avoidance are associated with greater increases in ACh and states of reward are associated with greater dopamine release. While the mu-opioid agonist, morphine, acutely increases the release of NAc dopamine and decreases ACh, the mu-opioid antagonist, naloxone, results in decreased dopamine and increased ACh [165]. Similarly, opiate antagonists can attenuate ethanol-induced increases in NAc dopamine release [166, 167], while causing a significant rise in NAc ACh [73].

One mechanism for these dopaminergic effects could be via mu-opioid inhibition of GABA inhibition (i.e. disinhibition) of dopamine cells in the ventral tegmental area in rewarding states $[131,168,169]$ and dynorphin-mediated activation of GABA (thus, inhibition of dopamine) cells in aversive states [131, 133, 141, 170,171]. Conversely, central ACh is elevated by striatal dynorphin infusion [172] and decreases with acute mu-opioid stimulation $[170,173,174]$.

Overall, although acutely aversive stimuli globally activate the opioid system, chronic states of aversion seem to be marked by decreased mu-opioid transmission and increased kappaopioid transmission via dynorphin, which has implications for the central dopamine/ACh balance.

\section{Implications for reward seeking}

It is well-established that individuals in a chronic aversive state, such as depression, chronic pain, or eating disorder, are more likely to have co-morbid addictive disorders [97, 98, 175178]. This underscores the overlapping systems implicated in reward and aversion. In particular, brain dopamine decreases observed after prolonged/repeated exposure to aversive stimuli are in line with the "reward deficiency hypothesis" of addiction, whereby an individual seeks out rewarding stimuli to compensate for diminished dopamine [179-183]. Drug addicts demonstrate a decreased sensitivity of reward circuits, similar to that seen in obesity and depression $[85,179-181,184-189]$, and thus, these individuals may require more of a substance (i.e. food or drug) to achieve normal mood elevations. Consequently, attempts to mitigate the unpleasantness of aversive states often involve the original aversive stimuli (i.e. drug use, binge eating) and perpetuate the problem. For example, substance abusers return to drug use to escape the unpleasant effects of withdrawal [190] or obese and bulimic individuals may binge eat to avoid feelings of depression [190-192]. Ultimately, though, these behaviors reinforce the neurobiological imbalances indicative of aversion.

Although the aversive states discussed in this paper have different behavioral manifestations, the degree of symptom cross-over and the similar neurotransmitter 
involvement suggest that the underlying neurobiology can be generalized to different conditions. A common theme in these conditions appears to be a central reward deficit that makes the individual more vulnerable to addictive behaviors.

\section{Conclusion}

Reward and aversion seem to be mediated by overlapping neural systems. Although they are often known as students of reward states, Bartley Hoebel and colleagues have made significant advances in understanding the neurobiology of aversion and the link between aversive states and addictive behaviors. These two dichotomous states may reflect an affective continuum contingent upon environmental conditions. For example, lateralhypothalamic stimulation may be perceived as rewarding to a food-deprived animal, yet aversive to an overfed animal [1]. Similarly, the taste of sucrose solution that is initially rated as "pleasant" shifts to "unpleasant" after a large meal of sucrose [193]. With drugs of abuse, initial intake causes euphoria, while repeated exposure triggers dysphoria and anhedonia [139].

Descriptive and mechanistic studies pioneered by Bartley Hoebel and others have demonstrated that the shift in the reward-aversion spectrum may be, in part, a result of changes in central dopamine/ACh ratio, particularly in the NAc. The path to aversion appears to be reduced dopamine activity and increased ACh activity in "reward centers" of the brain and kappa- and mu-opioid receptors may have a neuromodulatory role on both of these neurotransmitters.

\section{Acknowledgments}

Studies from our laboratory presented in this article were made possible through the generous support of the National Institutes of Health (DK065872, ARRA 3R01DK065872, F31DA023760) and a Smith Family Foundation Award of Excellence in Biomedical Research (ENP).

\section{References}

1. Hoebel BG. Brain reward and aversion systems in the control of feeding and sexual behavior. Nebr Symp Motiv. 1975; 22:49-112. [PubMed: 1107869]

2. Vowles KE, McNeil DW, Sorrell JT, Lawrence SM. Fear and pain: investigating the interaction between aversive states. J Abnorm Psychol. 2006; 115:821-33. [PubMed: 17100540]

3. Arkoff A. Resolution of approach-approach and avoidance-avoidance conflicts. J Abnorm Psychol. 1957; 55:402-4. [PubMed: 13474924]

4. Bates HD. Relevance of animal-avoidance analogue studies to the treatment of clinical phobias: a rejoinder to Cooper, Furst, and Bridger. J Abnorm Psychol. 1970; 75:12-4. [PubMed: 5416038]

5. Pollack D. Coping and avoidance in inebriated alcoholics and normals. J Abnorm Psychol. 1966; 71:417-9. [PubMed: 5978030]

6. Schmauk FJ. Punishment, arousal, and avoidance learning in sociopaths. J Abnorm Psychol. 1970; 76:325-35. [PubMed: 4395258]

7. Sidman M. On the persistence of avoidance behavior. J Abnorm Psychol. 1955; 50:217-20. [PubMed: 14366882]

8. Feldner MT, Hekmat H, Zvolensky MJ, Vowles KE, Secrist Z, Leen-Feldner EW. The role of experiential avoidance in acute pain tolerance: a laboratory test. J Behav Ther Exp Psychiatry. 2006; 37:146-58. [PubMed: 15882839]

9. Kiyatkin EA. Dopaminergic involvement in nociceptive sensitivity/behavioral reactivity regulation during aversive states of different nature in the rat. Int J Neurosci. 1989a; 44:111-33. [PubMed: 2562051] 
10. Moore KE, Lariviere EW. Effects Of D-Amphetamine And Restraint On The Content Of Norepinephrine And Dopamine In Rat Brain. Biochem Pharmacol. 1963; 12:1283-8. [PubMed: 14078917]

11. Mark GP, Weinberg JB, Rada PV, Hoebel BG. Extracellular acetylcholine is increased in the nucleus accumbens following the presentation of an aversively conditioned taste stimulus. Brain Res. 1995; 688:184-8. [PubMed: 8542305]

12. Hoebel BG. Hypothalamic self-stimulation and stimulation escape in relation to feeding and mating. Fed Proc. 1979; 38:2454-61. [PubMed: 385351]

13. Kiyatkin EA. Nociceptive sensitivity/behavioral reactivity regulation in rats during aversive states of different nature: its mediation by opioid peptides. Int J Neurosci. 1989b; 44:91-110. [PubMed: 2485833]

14. Zhang XJ, Zhang TW, Hu SJ, Xu H. Behavioral assessments of the aversive quality of pain in animals. Neurosci Bull. 2011; 27:61-7. [PubMed: 21270905]

15. Crane JW, Windels F, Sah P. Oscillations in the basolateral amygdala: aversive stimulation is state dependent and resets the oscillatory phase. J Neurophysiol. 2009; 102:1379-87. [PubMed: 19571185]

16. LeDoux J. The emotional brain, fear, and the amygdala. Cell Mol Neurobiol. 2003; 23:727-38. [PubMed: 14514027]

17. Sah P, Westbrook RF, Luthi A. Fear conditioning and long-term potentiation in the amygdala: what really is the connection? Ann N Y Acad Sci. 2008; 1129:88-95. [PubMed: 18591471]

18. Hernandez L, Hoebel BG. Food intake and lateral hypothalamic self-stimulation covary after medial hypothalamic lesions or ventral midbrain 6-hydroxydopamine injections that cause obesity. Behav Neurosci. 1989; 103:412-22. [PubMed: 2495804]

19. Hoebel BG. Inhibition and disinhibition of self-stimulation and feeding: hypothalamic control and postingestional factors. J Comp Physiol Psychol. 1968; 66:89-100. [PubMed: 5672645]

20. Hoebel BG. Feeding and self-stimulation. Ann N Y Acad Sci. 1969; 157:758-78. [PubMed: 5255639]

21. Hoebel BG, Avena NM, Rada P. Accumbens dopamine-acetylcholine balance in approach and avoidance. Curr Opin Pharmacol. 2007; 7:617-27. [PubMed: 18023617]

22. Hoebel BG, Leibowitz SF. Brain monoamines in the modulation of self-stimulation, feeding, and body weight. Res Publ Assoc Res Nerv Ment Dis. 1981; 59:103-42. [PubMed: 6109365]

23. Hoebel BG, Thompson RD. Aversion to lateral hypothalamic stimulation caused by intragastric feeding or obesity. J Comp Physiol Psychol. 1969; 68:536-43. [PubMed: 5344503]

24. Rada PV, Hoebel BG. Aversive hypothalamic stimulation releases acetylcholine in the nucleus accumbens, and stimulation-escape decreases it. Brain Res. 2001; 888:60-5. [PubMed: 11146052]

25. Rada PV, Mark GP, Hoebel BG. Dopamine release in the nucleus accumbens by hypothalamic stimulation-escape behavior. Brain Res. 1998; 782:228-34. [PubMed: 9519267]

26. Rada PV, Mark GP, Yeomans JJ, Hoebel BG. Acetylcholine release in ventral tegmental area by hypothalamic self-stimulation, eating, and drinking. Pharmacol Biochem Behav. 2000; 65:375-9. [PubMed: 10683476]

27. Henningsen P, Lowe B. Depression, pain, and somatoform disorders. Curr Opin Psychiatry. 2006; 19:19-24. [PubMed: 16612174]

28. Wood PB, Schweinhardt P, Jaeger E, Dagher A, Hakyemez H, Rabiner EA, et al. Fibromyalgia patients show an abnormal dopamine response to pain. Eur J Neurosci. 2007; 25:3576-82. [PubMed: 17610577]

29. Woolf CJ. Evidence for a central component of post-injury pain hypersensitivity. Nature. 1983; 306:686-8. [PubMed: 6656869]

30. Chapman CR, Tuckett RP, Song CW. Pain and stress in a systems perspective: reciprocal neural, endocrine, and immune interactions. J Pain. 2008; 9:122-45. [PubMed: 18088561]

31. Kundermann B, Krieg JC, Schreiber W, Lautenbacher S. The effect of sleep deprivation on pain. Pain Res Manag. 2004; 9:25-32. [PubMed: 15007400] 
32. Apkarian AV, Sosa Y, Sonty S, Levy RM, Harden RN, Parrish TB, et al. Chronic back pain is associated with decreased prefrontal and thalamic gray matter density. J Neurosci. 2004; 24:10410-5. [PubMed: 15548656]

33. Hernandez L, Hoebel BG. Food reward and cocaine increase extracellular dopamine in the nucleus accumbens as measured by microdialysis. Life Sci. 1988; 42:1705-12. [PubMed: 3362036]

34. Hernandez L, Hoebel BG. Feeding and hypothalamic stimulation increase dopamine turnover in the accumbens. Physiol Behav. 1988; 44:599-606. [PubMed: 3237847]

35. Hoebel BG, Hernandez L, Schwartz DH, Mark GP, Hunter GA. Microdialysis studies of brain norepinephrine, serotonin, and dopamine release during ingestive behavior. Theoretical and clinical implications. Ann N Y Acad Sci. 1989; 575:171-91. discussion 92-3. [PubMed: 2699187]

36. Mifsud JC, Hernandez L, Hoebel BG. Nicotine infused into the nucleus accumbens increases synaptic dopamine as measured by in vivo microdialysis. Brain Res. 1989; 478:365-7. [PubMed: 2924134]

37. Pettit HO, Justice JB Jr. Dopamine in the nucleus accumbens during cocaine self-administration as studied by in vivo microdialysis. Pharmacol Biochem Behav. 1989; 34:899-904. [PubMed: 2623043]

38. Robinson TE, Jurson PA, Bennett JA, Bentgen KM. Persistent sensitization of dopamine neurotransmission in ventral striatum (nucleus accumbens) produced by prior experience with (+)amphetamine: a microdialysis study in freely moving rats. Brain Res. 1988; 462:211-22. [PubMed: 2847849]

39. Damsma G, Pfaus JG, Wenkstern D, Phillips AG, Fibiger HC. Sexual behavior increases dopamine transmission in the nucleus accumbens and striatum of male rats: comparison with novelty and locomotion. Behav Neurosci. 1992; 106:181-91. [PubMed: 1313243]

40. Pfaus JG, Phillips AG. Role of dopamine in anticipatory and consummatory aspects of sexual behavior in the male rat. Behav Neurosci. 1991; 105:727-43. [PubMed: 1840012]

41. Imperato A, Cabib S, Puglisi-Allegra S. Repeated stressful experiences differently affect the timedependent responses of the mesolimbic dopamine system to the stressor. Brain Res. 1993; 601:333-6. [PubMed: 8431783]

42. McCullough LD, Sokolowski JD, Salamone JD. A neurochemical and behavioral investigation of the involvement of nucleus accumbens dopamine in instrumental avoidance. Neuroscience. 1993; 52:919-25. [PubMed: 8450978]

43. Salamone JD. The involvement of nucleus accumbens dopamine in appetitive and aversive motivation. Behav Brain Res. 1994; 61:117-33. [PubMed: 8037860]

44. Niemegeers CJ, Verbruggen FJ, Janssen PA. The influence of various neuroleptic drugs on shock avoidance responding in rats. I. Nondiscriminated Sidman avoidance procedure. Psychopharmacologia. 1969; 16:161-74. [PubMed: 5364169]

45. Lavielle S, Tassin JP, Thierry AM, Blanc G, Herve D, Barthelemy C, et al. Blockade by benzodiazepines of the selective high increase in dopamine turnover induced by stress in mesocortical dopaminergic neurons of the rat. Brain Res. 1979; 168:585-94. [PubMed: 435982]

46. Abercrombie ED, Keefe KA, DiFrischia DS, Zigmond MJ. Differential effect of stress on in vivo dopamine release in striatum, nucleus accumbens, and medial frontal cortex. J Neurochem. 1989; 52:1655-8. [PubMed: 2709017]

47. Thierry AM, Tassin JP, Blanc G, Glowinski J. Selective activation of mesocortical DA system by stress. Nature. 1976; 263:242-4. [PubMed: 958479]

48. Fadda F, Melis MR, Argiolas A. Effect of electric foot shock on dopamine and 3,4dihydroxyphenylacetic acid (DOPAC) in different brain areas of rats. Boll Soc Ital Biol Sper. 1978; 54:1747-50. [PubMed: 753259]

49. Tissari AH, Argiolas A, Fadda F, Serra G, Gessa GL. Foot-shock stress accelerates non-striatal dopamine synthesis without activating tyrosine hydroxylase. Naunyn Schmiedebergs Arch Pharmacol. 1979; 308:155-7. [PubMed: 41189]

50. Boutelle MG, Zetterstrom T, Pei Q, Svensson L, Fillenz M. In vivo neurochemical effects of tail pinch. J Neurosci Methods. 1990; 34:151-7. [PubMed: 2259236] 
51. Imperato A, Puglisi-Allegra S, Casolini P, Zocchi A, Angelucci L. Stress-induced enhancement of dopamine and acetylcholine release in limbic structures: role of corticosterone. Eur J Pharmacol. 1989; 165:337-8. [PubMed: 2776836]

52. Finlay JM, Zigmond MJ. The effects of stress on central dopaminergic neurons: possible clinical implications. Neurochem Res. 1997; 22:1387-94. [PubMed: 9355111]

53. Kiyatkin EA. Dopaminergic involvement in nociceptive sensitivity/behavioral reactivity regulation during aversive states of different nature in the rat. Int J Neurosci. 1989; 44:111-33. [PubMed: 2562051]

54. Snyder AM, Stricker EM, Zigmond MJ. Stress-induced neurological impairments in an animal model of parkinsonism. Ann Neurol. 1985; 18:544-51. [PubMed: 3935041]

55. Mark GP, Blander DS, Hoebel BG. A conditioned stimulus decreases extracellular dopamine in the nucleus accumbens after the development of a learned taste aversion. Brain Res. 1991; 551:30810. [PubMed: 1913157]

56. Cabib S, Puglisi-Allegra S. Opposite responses of mesolimbic dopamine system to controllable and uncontrollable aversive experiences. J Neurosci. 1994; 14:3333-40. [PubMed: 8182476]

57. Niikura K, Narita M, Butelman ER, Kreek MJ, Suzuki T. Neuropathic and chronic pain stimuli downregulate central mu-opioid and dopaminergic transmission. Trends Pharmacol Sci. 2010; 31:299-305. [PubMed: 20471111]

58. Niikura K, Narita M, Narita M, Nakamura A, Okutsu D, Ozeki A, et al. Direct evidence for the involvement of endogenous beta-endorphin in the suppression of the morphine-induced rewarding effect under a neuropathic pain-like state. Neurosci Lett. 2008; 435:257-62. [PubMed: 18359165]

59. Pais-Vieira M, Mendes-Pinto MM, Lima D, Galhardo V. Cognitive impairment of prefrontaldependent decision-making in rats after the onset of chronic pain. Neuroscience. 2009; 161:671-9. [PubMed: 19362121]

60. Grachev ID, Fredrickson BE, Apkarian AV. Abnormal brain chemistry in chronic back pain: an in vivo proton magnetic resonance spectroscopy study. Pain. 2000; 89:7-18. [PubMed: 11113288]

61. Yang YK, Yeh TL, Yao WJ, Lee IH, Chen PS, Chiu NT, et al. Greater availability of dopamine transporters in patients with major depression--a dual-isotope SPECT study. Psychiatry Res. 2008; 162:230-5. [PubMed: 18295460]

62. Leentjens AF. The role of dopamine agonists in the treatment of depression in patients with Parkinson's disease: a systematic review. Drugs. 2011; 71:273-86. [PubMed: 21319866]

63. Picillo M, Rocco M, Barone P. Dopamine receptor agonists and depression in Parkinson's disease. Parkinsonism Relat Disord. 2009; 15 (Suppl 4):S81-4. [PubMed: 20123564]

64. Clausius N, Born C, Grunze H. The relevance of dopamine agonists in the treatment of depression. Neuropsychiatr. 2009; 23:15-25. [PubMed: 19272288]

65. Porsolt RD, Anton G, Blavet N, Jalfre M. Behavioural despair in rats: a new model sensitive to antidepressant treatments. Eur J Pharmacol. 1978; 47:379-91. [PubMed: 204499]

66. Rossetti ZL, Lai M, Hmaidan Y, Gessa GL. Depletion of mesolimbic dopamine during behavioral despair: partial reversal by chronic imipramine. Eur J Pharmacol. 1993; 242:313-5. [PubMed: 8281997]

67. Park SK, Nguyen MD, Fischer A, Luke MP, Affar el B, Dieffenbach PB, et al. Par-4 links dopamine signaling and depression. Cell. 2005; 122:275-87. [PubMed: 16051151]

68. Martinez D, Broft A, Foltin RW, Slifstein M, Hwang DR, Huang Y, et al. Cocaine dependence and $\mathrm{d} 2$ receptor availability in the functional subdivisions of the striatum: relationship with cocaineseeking behavior. Neuropsychopharmacology. 2004; 29:1190-202. [PubMed: 15010698]

69. Natividad LA, Tejeda HA, Torres OV, O'Dell LE. Nicotine withdrawal produces a decrease in extracellular levels of dopamine in the nucleus accumbens that is lower in adolescent versus adult male rats. Synapse. 2010; 64:136-45. [PubMed: 19771590]

70. Hadjiconstantinou M, Duchemin AM, Zhang H, Neff NH. Enhanced dopamine transporter function in striatum during nicotine withdrawal. Synapse. 2011; 65:91-8. [PubMed: 20506223]

71. Pothos E, Rada P, Mark GP, Hoebel BG. Dopamine microdialysis in the nucleus accumbens during acute and chronic morphine, naloxone-precipitated withdrawal and clonidine treatment. Brain Res. 1991; 566:348-50. [PubMed: 1814554] 
72. Rada P, Jensen K, Hoebel BG. Effects of nicotine and mecamylamine-induced withdrawal on extracellular dopamine and acetylcholine in the rat nucleus accumbens. Psychopharmacology (Berl). 2001; 157:105-10. [PubMed: 11512050]

73. Rada P, Johnson DF, Lewis MJ, Hoebel BG. In alcohol-treated rats, naloxone decreases extracellular dopamine and increases acetylcholine in the nucleus accumbens: evidence of opioid withdrawal. Pharmacol Biochem Behav. 2004; 79:599-605. [PubMed: 15582668]

74. Weiss F, Markou A, Lorang MT, Koob GF. Basal extracellular dopamine levels in the nucleus accumbens are decreased during cocaine withdrawal after unlimited-access self-administration. Brain Res. 1992; 593:314-8. [PubMed: 1450939]

75. Rada PV, Mark GP, Taylor KM, Hoebel BG. Morphine and naloxone, i.p. or locally, affect extracellular acetylcholine in the accumbens and prefrontal cortex. Pharmacol Biochem Behav. 1996; 53:809-16. [PubMed: 8801582]

76. Koob GF, Le Moal M. Addiction and the brain antireward system. Annu Rev Psychol. 2008; 59:29-53. [PubMed: 18154498]

77. Avena NM, Rada P, Hoebel BG. Evidence for sugar addiction: behavioral and neurochemical effects of intermittent, excessive sugar intake. Neurosci Biobehav Rev. 2008; 32:20-39. [PubMed: 17617461]

78. Avena NM, Rada P, Hoebel BG. Sugar and fat bingeing have notable differences in addictive-like behavior. J Nutr. 2009; 139:623-8. [PubMed: 19176748]

79. Colantuoni C, Rada P, McCarthy J, Patten C, Avena NM, Chadeayne A, et al. Evidence that intermittent, excessive sugar intake causes endogenous opioid dependence. Obes Res. 2002; 10:478-88. [PubMed: 12055324]

80. Spangler R, Wittkowski KM, Goddard NL, Avena NM, Hoebel BG, Leibowitz SF. Opiate-like effects of sugar on gene expression in reward areas of the rat brain. Brain Res Mol Brain Res. 2004; 124:134-42. [PubMed: 15135221]

81. Avena NM, Rada P, Moise N, Hoebel BG. Sucrose sham feeding on a binge schedule releases accumbens dopamine repeatedly and eliminates the acetylcholine satiety response. Neuroscience. 2006; 139:813-20. [PubMed: 16460879]

82. Rada P, Avena NM, Hoebel BG. Daily bingeing on sugar repeatedly releases dopamine in the accumbens shell. Neuroscience. 2005; 134:737-44. [PubMed: 15987666]

83. Wang GJ, Volkow ND, Logan J, Pappas NR, Wong CT, Zhu W, et al. Brain dopamine and obesity. Lancet. 2001; 357:354-7. [PubMed: 11210998]

84. Rada P, Bocarsly ME, Barson JR, Hoebel BG, Leibowitz SF. Reduced accumbens dopamine in Sprague-Dawley rats prone to overeating a fat-rich diet. Physiol Behav. 2010; 101:394-400. [PubMed: 20643155]

85. Volkow ND, Wang GJ, Baler RD. Reward, dopamine and the control of food intake: implications for obesity. Trends Cogn Sci. 2011; 15:37-46. [PubMed: 21109477]

86. Spangler R, Goddard NL, Avena NM, Hoebel BG, Leibowitz SF. Elevated D3 dopamine receptor mRNA in dopaminergic and dopaminoceptive regions of the rat brain in response to morphine. Brain Res Mol Brain Res. 2003; 111:74-83. [PubMed: 12654507]

87. Colantuoni C, Schwenker J, McCarthy J, Rada P, Ladenheim B, Cadet JL, et al. Excessive sugar intake alters binding to dopamine and mu-opioid receptors in the brain. Neuroreport. 2001; 12:3549-52. [PubMed: 11733709]

88. Bello NT, Lucas LR, Hajnal A. Repeated sucrose access influences dopamine D2 receptor density in the striatum. Neuroreport. 2002; 13:1575-8. [PubMed: 12218708]

89. Imperato A, Obinu MC, Carta G, Mascia MS, Casu MA, Gessa GL. Reduction of dopamine release and synthesis by repeated amphetamine treatment: role in behavioral sensitization. Eur J Pharmacol. 1996; 317:231-7. [PubMed: 8997605]

90. Vanderschuren LJ, Kalivas PW. Alterations in dopaminergic and glutamatergic transmission in the induction and expression of behavioral sensitization: a critical review of preclinical studies. Psychopharmacology (Berl). 2000; 151:99-120. [PubMed: 10972458]

91. Unterwald EM, Kreek MJ, Cuntapay M. The frequency of cocaine administration impacts cocaineinduced receptor alterations. Brain Res. 2001; 900:103-9. [PubMed: 11325352] 
92. Pothos EN, Creese I, Hoebel BG. Restricted eating with weight loss selectively decreases extracellular dopamine in the nucleus accumbens and alters dopamine response to amphetamine, morphine, and food intake. J Neurosci. 1995; 15:6640-50. [PubMed: 7472425]

93. Carroll ME, France CP, Meisch RA. Food deprivation increases oral and intravenous drug intake in rats. Science. 1979; 205:319-21. [PubMed: 36665]

94. Carroll ME, Stotz DC. Oral d-amphetamine and ketamine self-administration by rhesus monkeys: effects of food deprivation. J Pharmacol Exp Ther. 1983; 227:28-34. [PubMed: 6684685]

95. Carroll ME. The role of food deprivation in the maintenance and reinstatement of cocaine-seeking behavior in rats. Drug Alcohol Depend. 1985; 16:95-109. [PubMed: 4075974]

96. Papasava M, Singer G. Self-administration of low-dose cocaine by rats at reduced and recovered body weight. Psychopharmacology (Berl). 1985; 85:419-25. [PubMed: 3927337]

97. Courbasson CM, Smith PD, Cleland PA. Substance use disorders, anorexia, bulimia, and concurrent disorders. Can J Public Health. 2005; 96:102-6. [PubMed: 15850027]

98. Herzog DB, Franko DL, Dorer DJ, Keel PK, Jackson S, Manzo MP. Drug abuse in women with eating disorders. Int J Eat Disord. 2006; 39:364-8. [PubMed: 16565976]

99. Frieling H, Romer KD, Scholz S, Mittelbach F, Wilhelm J, De Zwaan M, et al. Epigenetic dysregulation of dopaminergic genes in eating disorders. Int J Eat Disord. 2010; 43:577-83. [PubMed: 19728374]

100. Gross HA, Lake CR, Ebert MH, Ziegler MG, Kopin IJ. Catecholamine metabolism in primary anorexia nervosa. J Clin Endocrinol Metab. 1979; 49:805-9. [PubMed: 511970]

101. Halmi KA, Dekirmenjian H, Davis JM, Casper R, Goldberg S. Catecholamine metabolism in anorexia nervosa. Arch Gen Psychiatry. 1978; 35:458-60. [PubMed: 727897]

102. Surmeier DJ, Ding J, Day M, Wang Z, Shen W. D1 and D2 dopamine-receptor modulation of striatal glutamatergic signaling in striatal medium spiny neurons. Trends Neurosci. 2007; 30:228-35. [PubMed: 17408758]

103. Kaneko S, Hikida T, Watanabe D, Ichinose H, Nagatsu T, Kreitman RJ, et al. Synaptic integration mediated by striatal cholinergic interneurons in basal ganglia function. Science. 2000; 289:6337. [PubMed: 10915629]

104. Mark GP, Rada PV, Shors TJ. Inescapable stress enhances extracellular acetylcholine in the rat hippocampus and prefrontal cortex but not the nucleus accumbens or amygdala. Neuroscience. 1996; 74:767-74. [PubMed: 8884772]

105. Imperato A, Puglisi-Allegra S, Casolini P, Angelucci L. Changes in brain dopamine and acetylcholine release during and following stress are independent of the pituitary-adrenocortical axis. Brain Res. 1991; 538:111-7. [PubMed: 2018923]

106. Dazzi L, Motzo C, Imperato A, Serra M, Gessa GL, Biggio G. Modulation of basal and stressinduced release of acetylcholine and dopamine in rat brain by abecarnil and imidazenil, two anxioselective gamma-aminobutyric acidA receptor modulators. J Pharmacol Exp Ther. 1995; 273:241-7. [PubMed: 7714771]

107. Mark GP, Rada P, Pothos E, Hoebel BG. Effects of feeding and drinking on acetylcholine release in the nucleus accumbens, striatum, and hippocampus of freely behaving rats. J Neurochem. 1992; 58:2269-74. [PubMed: 1573406]

108. Helm KA, Rada P, Hoebel BG. Cholecystokinin combined with serotonin in the hypothalamus limits accumbens dopamine release while increasing acetylcholine: a possible satiation mechanism. Brain Res. 2003; 963:290-7. [PubMed: 12560135]

109. Rada PV, Hoebel BG. Supraadditive effect of d-fenfluramine plus phentermine on extracellular acetylcholine in the nucleus accumbens: possible mechanism for inhibition of excessive feeding and drug abuse. Pharmacol Biochem Behav. 2000; 65:369-73. [PubMed: 10683475]

110. Hoebel, BG.; Rada, P.; Mark, GP.; Pothos, E. Neural Systems for reinforcement and inhibtion of behavior: relevance to eating, addiction, and depression. In: Kahneman, D.; Diener, E.; Schwartz, N., editors. Well-being: The Foundation of Hedonic Psychology. Russel Sage Foundation; 1999. p. $558-72$.

111. Chau D, Rada PV, Kosloff RA, Hoebel BG. Cholinergic, M1 receptors in the nucleus accumbens mediate behavioral depression. A possible downstream target for fluoxetine. Ann N Y Acad Sci. 1999; 877:769-74. [PubMed: 10415702] 
112. Chau DT, Rada P, Kosloff RA, Taylor JL, Hoebel BG. Nucleus accumbens muscarinic receptors in the control of behavioral depression: antidepressant-like effects of local M1 antagonist in the Porsolt swim test. Neuroscience. 2001; 104:791-8. [PubMed: 11440810]

113. Glowa JR, Rice KC, Matecka D, Rothman RB. Phentermine/fenfluramine decreases cocaine selfadministration in rhesus monkeys. Neuroreport. 1997; 8:1347-51. [PubMed: 9172133]

114. Williams MJ, Adinoff B. The role of acetylcholine in cocaine addiction. Neuropsychopharmacology. 2008; 33:1779-97. [PubMed: 17928814]

115. Zhou W, Liu H, Zhang F, Tang S, Zhu H, Lai M, et al. Role of acetylcholine transmission in nucleus accumbens and ventral tegmental area in heroin-seeking induced by conditioned cues. Neuroscience. 2007; 144:1209-18. [PubMed: 17184925]

116. Hikida T, Kitabatake Y, Pastan I, Nakanishi S. Acetylcholine enhancement in the nucleus accumbens prevents addictive behaviors of cocaine and morphine. Proc Natl Acad Sci U S A. 2003; 100:6169-73. [PubMed: 12721372]

117. Rada P, Mark GP, Pothos E, Hoebel BG. Systemic morphine simultaneously decreases extracellular acetylcholine and increases dopamine in the nucleus accumbens of freely moving rats. Neuropharmacology. 1991; 30:1133-6. [PubMed: 1758589]

118. Stinus L, Le Moal M, Koob GF. Nucleus accumbens and amygdala are possible substrates for the aversive stimulus effects of opiate withdrawal. Neuroscience. 1990; 37:767-73. [PubMed: 2247222]

119. Rada P, Colasante C, Skirzewski M, Hernandez L, Hoebel B. Behavioral depression in the swim test causes a biphasic, long-lasting change in accumbens acetylcholine release, with partial compensation by acetylcholinesterase and muscarinic-1 receptors. Neuroscience. 2006; 141:6776. [PubMed: 16677771]

120. Detke MJ, Rickels M, Lucki I. Active behaviors in the rat forced swimming test differentially produced by serotonergic and noradrenergic antidepressants. Psychopharmacology (Berl). 1995; 121:66-72. [PubMed: 8539342]

121. Rada PV, Mark GP, Hoebel BG. In vivo modulation of acetylcholine in the nucleus accumbens of freely moving rats: I. Inhibition by serotonin. Brain Res. 1993; 619:98-104. [PubMed: 8374797]

122. Rasmussen NA, Farr LA. Beta-endorphin response to an acute pain stimulus. J Neurosci Methods. 2009; 177:285-8. [PubMed: 19007812]

123. Zubieta JK, Smith YR, Bueller JA, Xu Y, Kilbourn MR, Jewett DM, et al. Regional mu opioid receptor regulation of sensory and affective dimensions of pain. Science. 2001; 293:311-5. [PubMed: 11452128]

124. Narita M, Suzuki M, Imai S, Narita M, Ozaki S, Kishimoto Y, et al. Molecular mechanism of changes in the morphine-induced pharmacological actions under chronic pain-like state: suppression of dopaminergic transmission in the brain. Life Sci. 2004; 74:2655-73. [PubMed: 15041447]

125. Ozaki S, Narita M, Narita M, Iino M, Miyoshi K, Suzuki T. Suppression of the morphine-induced rewarding effect and G-protein activation in the lower midbrain following nerve injury in the mouse: involvement of G-protein-coupled receptor kinase 2. Neuroscience. 2003; 116:89-97. [PubMed: 12535942]

126. Ozaki S, Narita M, Narita M, Iino M, Sugita J, Matsumura Y, et al. Suppression of the morphineinduced rewarding effect in the rat with neuropathic pain: implication of the reduction in muopioid receptor functions in the ventral tegmental area. J Neurochem. 2002; 82:1192-8. [PubMed: 12358766]

127. Zangen A, Herzberg U, Vogel Z, Yadid G. Nociceptive stimulus induces release of endogenous beta-endorphin in the rat brain. Neuroscience. 1998; 85:659-62. [PubMed: 9639262]

128. Eisenberg E, McNicol ED, Carr DB. Efficacy and safety of opioid agonists in the treatment of neuropathic pain of nonmalignant origin: systematic review and meta-analysis of randomized controlled trials. Jama. 2005; 293:3043-52. [PubMed: 15972567]

129. Passik SD. Issues in long-term opioid therapy: unmet needs, risks, and solutions. Mayo Clin Proc. 2009; 84:593-601. [PubMed: 19567713]

130. Suzuki T. Modification of morphine dependence under chronic pain and its mechanism. Yakugaku Zasshi. 2001; 121:909-14. [PubMed: 11766405] 
131. Di Chiara G, Imperato A. Opposite effects of mu and kappa opiate agonists on dopamine release in the nucleus accumbens and in the dorsal caudate of freely moving rats. J Pharmacol Exp Ther. 1988; 244:1067-80. [PubMed: 2855239]

132. Zhang Y, Butelman ER, Schlussman SD, Ho A, Kreek MJ. Effect of the kappa opioid agonist R-84760 on cocaine-induced increases in striatal dopamine levels and cocaine-induced place preference in C57BL/6J mice. Psychopharmacology (Berl). 2004a; 173:146-52. [PubMed: 14712342]

133. Zhang Y, Butelman ER, Schlussman SD, Ho A, Kreek MJ. Effect of the endogenous kappa opioid agonist dynorphin $\mathrm{A}(1-17)$ on cocaine-evoked increases in striatal dopamine levels and cocaine-induced place preference in C57BL/6J mice. Psychopharmacology (Berl). 2004b; 172:422-9. [PubMed: 14712335]

134. Maisonneuve IM, Archer S, Glick SD. U50,488, a kappa opioid receptor agonist, attenuates cocaine-induced increases in extracellular dopamine in the nucleus accumbens of rats. Neurosci Lett. 1994; 181:57-60. [PubMed: 7898771]

135. Land BB, Bruchas MR, Lemos JC, Xu M, Melief EJ, Chavkin C. The dysphoric component of stress is encoded by activation of the dynorphin kappa-opioid system. J Neurosci. 2008; 28:40714. [PubMed: 18184783]

136. Pan ZZ. mu-Opposing actions of the kappa-opioid receptor. Trends Pharmacol Sci. 1998; 19:948. [PubMed: 9584625]

137. Knoll AT, Carlezon WA Jr. Dynorphin, stress, and depression. Brain Res. 2010; 1314:56-73. [PubMed: 19782055]

138. McLaughlin JP, Marton-Popovici M, Chavkin C. Kappa opioid receptor antagonism and prodynorphin gene disruption block stress-induced behavioral responses. J Neurosci. 2003; 23:5674-83. [PubMed: 12843270]

139. Nestler EJ, Carlezon WA Jr. The mesolimbic dopamine reward circuit in depression. Biol Psychiatry. 2006; 59:1151-9. [PubMed: 16566899]

140. Shippenberg TS, Rea W. Sensitization to the behavioral effects of cocaine: modulation by dynorphin and kappa-opioid receptor agonists. Pharmacol Biochem Behav. 1997; 57:449-55. [PubMed: 9218269]

141. Bruijnzeel AW. kappa-Opioid receptor signaling and brain reward function. Brain Res Rev. 2009; 62:127-46. [PubMed: 19804796]

142. Shirayama Y, Ishida H, Iwata M, Hazama GI, Kawahara R, Duman RS. Stress increases dynorphin immunoreactivity in limbic brain regions and dynorphin antagonism produces antidepressant-like effects. J Neurochem. 2004; 90:1258-68. [PubMed: 15312181]

143. Kennedy SE, Koeppe RA, Young EA, Zubieta JK. Dysregulation of endogenous opioid emotion regulation circuitry in major depression in women. Arch Gen Psychiatry. 2006; 63:1199-208. [PubMed: 17088500]

144. Zubieta JK, Ketter TA, Bueller JA, Xu Y, Kilbourn MR, Young EA, et al. Regulation of human affective responses by anterior cingulate and limbic mu-opioid neurotransmission. Arch Gen Psychiatry. 2003; 60:1145-53. [PubMed: 14609890]

145. Liberzon I, Zubieta JK, Fig LM, Phan KL, Koeppe RA, Taylor SF. mu-Opioid receptors and limbic responses to aversive emotional stimuli. Proc Natl Acad Sci U S A. 2002; 99:7084-9. [PubMed: 12011464]

146. Drewnowski A, Krahn DD, Demitrack MA, Nairn K, Gosnell BA. Taste responses and preferences for sweet high-fat foods: evidence for opioid involvement. Physiol Behav. 1992; 51:371-9. [PubMed: 1313591]

147. Kelley AE, Bakshi VP, Haber SN, Steininger TL, Will MJ, Zhang M. Opioid modulation of taste hedonics within the ventral striatum. Physiol Behav. 2002; 76:365-77. [PubMed: 12117573]

148. Nathan PJ, Bullmore ET. From taste hedonics to motivational drive: central mu-opioid receptors and binge-eating behaviour. Int J Neuropsychopharmacol. 2009:1-14.

149. Dum J, Gramsch C, Herz A. Activation of hypothalamic beta-endorphin pools by reward induced by highly palatable food. Pharmacol Biochem Behav. 1983; 18:443-7. [PubMed: 6132412]

150. Brewerton TD, Lydiard RB, Laraia MT, Shook JE, Ballenger JC. CSF beta-endorphin and dynorphin in bulimia nervosa. Am J Psychiatry. 1992; 149:1086-90. [PubMed: 1353317] 
151. Bencherif B, Guarda AS, Colantuoni C, Ravert HT, Dannals RF, Frost JJ. Regional mu-opioid receptor binding in insular cortex is decreased in bulimia nervosa and correlates inversely with fasting behavior. J Nucl Med. 2005; 46:1349-51. [PubMed: 16085593]

152. Drewnowski A. Metabolic determinants of binge eating. Addict Behav. 1995; 20:733-45. [PubMed: 8820526]

153. Kelley AE, Will MJ, Steininger TL, Zhang M, Haber SN. Restricted daily consumption of a highly palatable food (chocolate Ensure(R)) alters striatal enkephalin gene expression. Eur J Neurosci. 2003; 18:2592-8. [PubMed: 14622160]

154. Demitrack MA, Putnam FW, Rubinow DR, Pigott TA, Altemus M, Krahn DD, et al. Relation of dissociative phenomena to levels of cerebrospinal fluid monoamine metabolites and betaendorphin in patients with eating disorders: a pilot study. Psychiatry Res. 1993; 49:1-10. [PubMed: 7511247]

155. Kreek MJ. Effects of opiates, opioid antagonists and cocaine on the endogenous opioid system: clinical and laboratory studies. NIDA Res Monogr. 1992; 119:44-8. [PubMed: 1435981]

156. Hollt V, Horn G. Nicotine and opioid peptides. Prog Brain Res. 1989; 79:187-93. [PubMed: 2587743]

157. Houdi AA, Bardo MT, Van Loon GR. Opioid mediation of cocaine-induced hyperactivity and reinforcement. Brain Res. 1989; 497:195-8. [PubMed: 2790454]

158. Seizinger BR, Bovermann K, Maysinger D, Hollt V, Herz A. Differential effects of acute and chronic ethanol treatment on particular opioid peptide systems in discrete regions of rat brain and pituitary. Pharmacol Biochem Behav. 1983; 18 (Suppl 1):361-9. [PubMed: 6138772]

159. Koob GF, Bloom FE. Cellular and molecular mechanisms of drug dependence. Science. 1988; 242:715-23. [PubMed: 2903550]

160. Olive MF, Koenig HN, Nannini MA, Hodge CW. Stimulation of endorphin neurotransmission in the nucleus accumbens by ethanol, cocaine, and amphetamine. J Neurosci. 2001; 21:RC184. [PubMed: 11717387]

161. Zubieta JK, Gorelick DA, Stauffer R, Ravert HT, Dannals RF, Frost JJ. Increased mu opioid receptor binding detected by PET in cocaine-dependent men is associated with cocaine craving. Nat Med. 1996; 2:1225-9. [PubMed: 8898749]

162. Heinz A, Reimold M, Wrase J, Hermann D, Croissant B, Mundle G, et al. Correlation of stable elevations in striatal mu-opioid receptor availability in detoxified alcoholic patients with alcohol craving: a positron emission tomography study using carbon 11-labeled carfentanil. Arch Gen Psychiatry. 2005; 62:57-64. [PubMed: 15630073]

163. Vescovi PP, Coiro V, Volpi R, Giannini A, Passeri M. Plasma beta-endorphin, but not metenkephalin levels are abnormal in chronic alcoholics. Alcohol Alcohol. 1992; 27:471-5. [PubMed: 1335722]

164. Nestler EJ. Molecular basis of long-term plasticity underlying addiction. Nat Rev Neurosci. 2001; 2:119-28. [PubMed: 11252991]

165. Rada P, Barson JR, Leibowitz SF, Hoebel BG. Opioids in the hypothalamus control dopamine and acetylcholine levels in the nucleus accumbens. Brain Res. 2010; 1312:1-9. [PubMed: 19948154]

166. Acquas E, Meloni M, Di Chiara G. Blockade of delta-opioid receptors in the nucleus accumbens prevents ethanol-induced stimulation of dopamine release. Eur J Pharmacol. 1993; 230:239-41. [PubMed: 8380771]

167. Gonzales RA, Weiss F. Suppression of ethanol-reinforced behavior by naltrexone is associated with attenuation of the ethanol-induced increase in dialysate dopamine levels in the nucleus accumbens. J Neurosci. 1998; 18:10663-71. [PubMed: 9852601]

168. Bergevin A, Girardot D, Bourque MJ, Trudeau LE. Presynaptic mu-opioid receptors regulate a late step of the secretory process in rat ventral tegmental area GABAergic neurons. Neuropharmacology. 2002; 42:1065-78. [PubMed: 12128008]

169. Leite-Morris KA, Fukudome EY, Shoeb MH, Kaplan GB. GABA(B) receptor activation in the ventral tegmental area inhibits the acquisition and expression of opiate-induced motor sensitization. J Pharmacol Exp Ther. 2004; 308:667-78. [PubMed: 14610238] 
170. Mulder AH, Wardeh G, Hogenboom F, Frankhuyzen AL. Kappa- and delta-opioid receptor agonists differentially inhibit striatal dopamine and acetylcholine release. Nature. 1984; 308:27880. [PubMed: 6322011]

171. Spanagel R, Herz A, Shippenberg TS. Opposing tonically active endogenous opioid systems modulate the mesolimbic dopaminergic pathway. Proc Natl Acad Sci U S A. 1992; 89:2046-50. [PubMed: 1347943]

172. Pani AK. Influence of intrastriatal infusion of dynorphin fragments on overflow of acetylcholine and dopamine in the rat brain. Int J Neurosci. 2009; 119:1362-83. [PubMed: 19922362]

173. Arenas E, Alberch J, Sanchez Arroyos R, Marsal J. Effect of opioids on acetylcholine release evoked by K+ or glutamic acid from rat neostriatal slices. Brain Res. 1990; 523:51-6. [PubMed: 1976420]

174. Beani L, Bianchi C, Borea PA, Siniscalchi A. Effects of chronic morphine treatment on opioidinduced inhibition and facilitation of acetylcholine release in guinea-pig thalamic slices. Pharmacol Res Commun. 1986; 18:591-600. [PubMed: 3749245]

175. Regier DA, Farmer ME, Rae DS, Locke BZ, Keith SJ, Judd LL, et al. Comorbidity of mental disorders with alcohol and other drug abuse. Results from the Epidemiologic Catchment Area (ECA) Study. Jama. 1990; 264:2511-8. [PubMed: 2232018]

176. Langas AM, Malt UF, Opjordsmoen S. Comorbid mental disorders in substance users from a single catchment area--a clinical study. BMC Psychiatry. 2011; 11:25. [PubMed: 21314980]

177. Meltzer-Brody, S.; Leserman, J. CNS Spectr. 2011. Psychiatric Comorbidity in Women with Chronic Pelvic Pain.

178. Kirsh KL, Whitcomb LA, Donaghy K, Passik SD. Abuse and addiction issues in medically ill patients with pain: attempts at clarification of terms and empirical study. Clin J Pain. 2002; 18:S52-60. [PubMed: 12479254]

179. Pothos EN, Sulzer D, Hoebel BG. Plasticity of quantal size in ventral midbrain dopamine neurons: possible implications for the neurochemistry of feeding and reward. Appetite. 1998; 31:405. [PubMed: 9920693]

180. Geiger BM, Behr GG, Frank LE, Caldera-Siu AD, Beinfeld MC, Kokkotou EG, et al. Evidence for defective mesolimbic dopamine exocytosis in obesity-prone rats. FASEB J. 2008; 22:2740-6. [PubMed: 18477764]

181. Geiger BM, Haburcak M, Avena NM, Moyer MC, Hoebel BG, Pothos EN. Deficits of mesolimbic dopamine neurotransmission in rat dietary obesity. Neuroscience. 2009; 159:1193-9. [PubMed: 19409204]

182. Blum K, Braverman ER, Holder JM, Lubar JF, Monastra VJ, Miller D, et al. Reward deficiency syndrome: a biogenetic model for the diagnosis and treatment of impulsive, addictive, and compulsive behaviors. J Psychoactive Drugs. 2000; 32(Suppl):i-iv. 1-112. [PubMed: 11280926]

183. Wang GJ, Volkow ND, Thanos PK, Fowler JS. Similarity between obesity and drug addiction as assessed by neurofunctional imaging: a concept review. J Addict Dis. 2004; 23:39-53. [PubMed: 15256343]

184. Volkow ND, Wang GJ, Fowler JS, Tomasi D, Telang F, Baler R. Addiction: decreased reward sensitivity and increased expectation sensitivity conspire to overwhelm the brain's control circuit. Bioessays. 2010; 32:748-55. [PubMed: 20730946]

185. Andrews MM, Meda SA, Thomas AD, Potenza MN, Krystal JH, Worhunsky P, et al. Individuals family history positive for alcoholism show functional magnetic resonance imaging differences in reward sensitivity that are related to impulsivity factors. Biol Psychiatry. 2011; 69:675-83. [PubMed: 21126735]

186. Stice E, Yokum S, Blum K, Bohon C. Weight gain is associated with reduced striatal response to palatable food. J Neurosci. 2010; 30:13105-9. [PubMed: 20881128]

187. Foti D, Hajcak G. State sadness reduces neural sensitivity to nonrewards versus rewards. Neuroreport. 2010; 21:143-7. [PubMed: 20010444]

188. Foti D, Hajcak G. Depression and reduced sensitivity to non-rewards versus rewards: Evidence from event-related potentials. Biol Psychol. 2009; 81:1-8. [PubMed: 19162124] 
189. Hasler G, Luckenbaugh DA, Snow J, Meyers N, Waldeck T, Geraci M, et al. Reward processing after catecholamine depletion in unmedicated, remitted subjects with major depressive disorder. Biol Psychiatry. 2009; 66:201-5. [PubMed: 19393989]

190. Barnes DM. Breaking the cycle of addiction. Science. 1988; 241:1029-30. [PubMed: 3413475]

191. Khaodhiar L, McCowen KC, Blackburn GL. Obesity and its comorbid conditions. Clin Cornerstone. 1999; 2:17-31. [PubMed: 10696282]

192. Jimerson DC, Lesem MD, Kaye WH, Hegg AP, Brewerton TD. Eating disorders and depression: is there a serotonin connection? Biol Psychiatry. 1990; 28:443-54. [PubMed: 2207221]

193. Cabanac M, Duclaux R, Spector NH. Sensory feedback in regulation of body weight: is there a ponderostat? Nature. 1971; 229:125-7. [PubMed: 4923100]

194. Tomazini FM, Reimer A, Albrechet-Souza L, Brandao ML. Opposite effects of short- and longduration isolation on ultrasonic vocalization, startle and prepulse inhibition in rats. J Neurosci Methods. 2006; 153:114-20. [PubMed: 16313968] 


\section{Highlights}

- Hoebel and colleagues advanced the study of behavior and neurobiology linked to acute and chronic aversive states.

- Reward and aversion may reflect an affective continuum contingent upon environmental conditions.

- Descriptive and mechanistic studies have demonstrated that the shift in the rewardaversion spectrum may reflect changes in mesolimbic dopamine/ acetylcholine ratio.

- Reward deficits associated with aversive states may predispose to addictive behaviors. 